OPEN ACCESS

Edited by:

Mary Leanoir Brydon-Miller, University of Louisville, United States

Reviewed by:

Davydd James Greenwood, Cornell University, United States Victor Jay Friedman,

Max Stern Academic College of Emek Yezreel, Israel

*Correspondence: Katharina Resch

katharina.resch@univie.ac.at

Specialty section: This article was submitted to Leadership in Education, a section of the journal

Frontiers in Education

Received: 06 February 2020 Accepted: 12 June 2020

Published: 21 July 2020

Citation:

Resch K, Fellner M, Fahrenwald C,

Slepcevic-Zach P, Knapp $M$ and Rameder P (2020) Embedding Social

Innovation and Service Learning in Higher Education's Third Sector Policy

Developments in Austria.

Front. Educ. 5:112.

doi: 10.3389/feduc.2020.00112

\section{Embedding Social Innovation and Service Learning in Higher Education's Third Sector Policy Developments in Austria}

\author{
Katharina Resch ${ }^{1 *}$, Magdalena Fellner ${ }^{2}$, Claudia Fahrenwald ${ }^{3}$, Peter Slepcevic-Zach ${ }^{4}$, \\ Mariella Knapp ${ }^{1}$ and Paul Rameder ${ }^{5}$ \\ ${ }^{1}$ Center for Teacher Education, University of Vienna, Vienna, Austria, ${ }^{2}$ Center for Educational Management and Higher \\ Education Development, Danube University Krems, Krems, Austria, ${ }^{3}$ Department of Educational Science, University of \\ Education Upper Austria, Linz, Austria, ${ }^{4}$ Department of Business Education and Development, University of Graz, Graz, \\ Austria, ${ }^{5}$ Social Entrepreneurship Center, Competence Center for Nonprofit Organisations and Social Entrepreneurship, \\ Vienna University of Economics and Business, Vienna, Austria
}

Social innovation in Austrian HEls is discussed under the headline of their "Third Mission." The HE sector is pressured to have more and more impact on society. Internationally speaking, many countries benefit from national policies and networks in the Third Sector, but policies in Austria were initiated only recently, in 2017, on a national level. Interestingly, the service learning approach as an innovative and socially responsible teaching methodology stands out in Austrian HE. This article classifies the developments of the Third Sector in Austria in the form of a policy brief. Austria has a growing community of practice in social innovation and service learning. The article gives insight into the strategic developments in Austria and is underpinned with recommendable action to be transferred to others.

Keywords: social innovation, third mission, higher education policies, service learning, civic engagement

\section{INTRODUCTION}

Throughout their long history, HEIs have regularly been confronted with intensive discussions about their position in society. HEIs have been facing a fundamental paradigm shift about what they are expected to accomplish on an economic, social, and environmental level. The old paradigm of scientific discovery ("Mode 1"), which was characterized by an internally-driven taxonomy of disciplines and the autonomy of researchers and their institutions, was superseded by a new paradigm of knowledge production ("Mode 2"), which is socially embedded, applied, transdisciplinary, and "subject to multiple accountabilities" (Nowotny et al., 2003, p. 179). As a consequence, the place of universities in society (Maassen et al., 2019) had to change as well. This placed an emphasis on activities in the Third Sector, which are neither governmental nor for-profit, but value-driven, and which operate between the state, the market, and the community (Evers and Laville, 2004).

While in the United States, Third Sector activities have been a central component of HE, European HEIs still lag behind. Scholars have discussed the adequacy of terminology for Third Sector activities, which are contextual and regional (Aramburuzabala et al., 2019). While in the Anglo-American context, civic engagement, community-based research, or action methodologies in the Third Sector are guiding terms (Nigro, 2017), the umbrella term "Third Mission" has 
prevailed in German-speaking countries. Additionally, there is a broad discourse about Social Innovation (BEPA, 2010), Social Responsibility (GUNI, 2009), Service Learning (Reinders, 2016) - concepts, which also shape the Third Sector discourse, however, we identified service learning as the central discursive element in the European Third Sector discussion.

Service learning has since the 1990ies emerged as a central component of $\mathrm{HE}$ in the United States connected to both civic responsibility and academic learning (Felten and Clayton, 2011). "Service-learning is the various pedagogies that link community service and academic study" (Ehrlich, 1996). While its potential lies in preparing students to be engaged citizens, it has many forms of implementation, including direct or indirect services in the Third Sector and community partners in the local neighborhood, on-campus, or even online. During implementation equal priority is given to students, staff/faculty, and community partners. According to Dewey (1966), a democratic society will only work with engaged citizens. Students, faculty, and community partners thereby build reciprocal relationships, which lead to both initial and sustained learning on all sides (Brower, 2011). Service learning was initially viewed as an opportunity to radically change $\mathrm{HE}$ and make it more relevant to communities (Boyer, 1996). The largest body of literature about community engagement has been produced in the US (Bringle and Hatcher, 1996; Furco, 2002), based on ideas of pragmatism (Harkavy and Benson, 1998), utilitarianism and communitarianism (Codispoti, 2004), and systemic engagement theory (McNall et al., 2015).

However, service learning as a Third Sector activity, is not free of criticism: Once thought to benefit local communities, it is now criticized for serving HEI goals, such as providing research laboratories for faculty and venues for students to implement applied coursework (Holland, 2005). Instead of helping to bring about transformational change in communities, service learning has become a technical practice with a "charity" orientation and in this sense mirrors a neoliberal approach in the transformation of HE (Raddon and Harrison, 2015). From this perspective, service learning is instrumentalized to appeal to external funders (Slaugther and Rhoades, 2000). Some researchers believe that service learning has positive effects on the social awareness of participants (Dukhan et al., 2009), while others are not that optimistic as evidence on the impact of service learning is missing. It may also reinforce paternalistic structures and stereotypes (Cipolle, 2004). Scholars are concerned with the Third Mission as elite practice (Butin, 2010). Service learning might be a luxury "many students cannot afford, be it in terms of time, finances, or job future" (Butin, 2010, p. 32). In order to prevent service learning from becoming just one more academic practice, students should be equipped to analyze policy and society (Wohnig, 2016).

In Europe, HEI's tripartite mission has only emerged since 2000. The so-called “Third Mission" has over the last two decades been positioned as an equally important part of the universities' social contract in Austria (Resch, 2018; Maassen et al., 2019). This article classifies the developments of the Third Mission in HE in Austria in the form of a policy brief. Austria has a growing community of practice in Third Sector policy, social innovation, and service learning, however, policy developments have never been summarized from a multi-stakeholder perspective.

\section{EUROPEAN HE POLICIES WITH PARTICULAR FOCUS ON AUSTRIA}

\section{European Developments}

While research in this area in the United States and other countries like Australia has prevailed, the academic discourse in Europe is still highly particularistic. The global network for innovation (GUNI), supported by UNESCO, argued for a renewal of $\mathrm{HE}$ with a vision of public service and social responsibility (GUNI, 2009). There is a "relatively enabling policy environment" for Third Mission activities in Europe (Aramburuzabala et al., 2019, p. 2). Spain, Ireland, and Germany have more well documented service learning histories than other European countries, and national networks. Austria's community of practice tends to be defined by scattered practice-a fact also true for other European countries, in which we discern "different levels of maturity and mainstreaming" of service learning (Aramburuzabala et al., 2019, p. 5). In post-communist countries, we observe a dynamic growth of the Third Sector and in parallel a continuing weakness of civic society, which may lead to barriers in the implementation of service learning (Meyer et al., 2019). In Western European countries, we see a stronger democratic culture that encourages students and faculty to actively participate in the community. In 2019, Austrian HEIs made a first move toward an emerging national network for service learning aiming at pulling isolated institutional practice together.

\section{Developmental Steps in HE Policy in Austria}

The HE sector in Austria covers 22 public universities, 21 universities of applied sciences, 14 teacher training colleges, and 16 private universities.

Official documents published by the Austrian government emphasize the relevance of an open HE system promoting university extension: "Outreach activities and diversity-sensitive course guidance" cited in the "National Strategy on the Social Dimension of Higher Education" published by the Federal Ministry of Science, Research and Economy (BMBWF, 2017) demonstrates the necessity for new forms of cooperation. Thus, HEIs are asked to "identify and expand collaboration with civic stakeholder groups" (ibid., p. 5). A joint publication by different Austrian ministries emphasizes the "reinforcement of community education approaches" (Republic of Austria, 2011 , p. 32) within the "Strategy for Life-long Learning in Austria (LLL:2020)." The "National Strategy on the Social Dimension of Higher Education" (ibid.) was developed as a joint policy document of all HEIs for the first time. In addition, service providers, intermediary bodies, and social partners contributed to the policy development process, which confirms the commitment of HE stakeholders in Austria to the paradigm shift in progress. 
In the recently published national government program for the period 2020-2024, one strategic objective is to "strengthen the knowledge transfer between science, industry and society" (Regierungsprogramm, 2020, p. 313). It targets an increased collaboration between science, arts, business, and other stakeholders to develop social innovation. Before 2017, policies on the Social Dimension were missing and generally left to the autonomy of HEIs, so a national strategy was not available. This led to less integrated and disseminated developments in Austria compared to other European countries with a national strategy or network. The title of the policy development ("Social Dimension"), which was used in Austria, allowed all institutions of various backgrounds and disciplines to join the process, as everyone accepted it.

\section{Institutional Practice}

In contrast to Germany, Ireland, or Spain, there are neither systematic attempts to evaluate the implementation of service learning, such as meta-analyses (Reinders, 2016), nor any form of overview study on the distribution of service learning in Austria.

Austria's community of practice tends to be defined by scattered institutional practice-a fact this policy brief is overcoming for the first time by pulling isolated institutional practice together. Given that Europe is one of the last international regions to consolidate the benefits of service learning, it is not surprising that there is no published policy brief on the situation of Austria's HE policy in the Third Sector so far. This is well reflected in institutional policies: Service learning is explicitly mentioned in the development plan 2019-2024 of the University of Graz, the development plan 2025 of the University of Vienna, the development plan of the University for Continuing Education at the Danube University Krems, the strategic plan 2019 of the Vienna University of Economics and Business, and in the development plan of the Universities of Education in Austria 2021-2026. It is therefore anchored in several strategic documents, however, not nationally organized. An increasing number of Austrian HEIs have been carrying out service learning courses (Gerholz and Losch, 2015; Resch, 2018). The University of Vienna launched a policy project on service learning in 2015 under the headline of their Third Mission. It was initiated from the rectorate (top management) and contained an awareness raising campaign and interviews with the deans of all faculties (middle management).

In 2010, the Vienna University of Economics and Business launched a community service learning program called Volunteering@WU, which aims at promoting learning and social inclusion by stimulating an exchange between students and young people from socially disadvantaged backgrounds (Buber et al., 2019). The program is co-curricular, participation is voluntary, and can therefore be classified as a hybrid of community service and service learning (Seider et al., 2013; Meyer and Schachermayer-Sporn, 2018). The University of Graz applies service learning as one form of social innovation in the Master Business Education and Development as a compulsory subject. Students work with a partner from outside the university, and e.g., develop a marketing concept for organic fruits or organize sales trainings for the long-term unemployed
(Slepcevic-Zach, 2017). "Civic Engagement Education and Service Learning in Teacher Education" at the University of Education Upper Austria is a fundamentally new concept for field experience for pre-service teachers: All candidates run through this experience as a mandatory course, including experience in social work, after-school and tutoring programs. This experience offers students insights in diverse living conditions, facilitates an understanding of individual biographies and social contexts (Grogan and Fahrenwald, 2018).

These examples of scattered practice show that in some cases, service learning as one configuration of social innovation forms an integral part of a study program, whereas in other programs students have the opportunity to choose the course as an elective subject. Austria is ready to leap into a new era of a shared community of service learning practice leaving scattered institutional practice behind-a paradigm shift from isolation to partnership.

\section{Actionable Recommendations}

Meijs et al. (2019) identified six barriers for implementing service learning: time for implementation, knowledge \& expertise, funding, prioritizing service learning on national and institutional level, a coordinating unit, and modes of recognition. We would like to emphasize the last three for Austria:

\section{Prioritizing Service Learning in Policy Development}

The implementation of existing policies in the Social Dimension is still vague, needs interpretation, and leads to scattered practice left to the autonomy of HEIs (with a lack of networking and practices shared). Following a self-assessment tool, Austria can be considered at Stage 1 (Critical Mass Building) of a threestage continuum of development (2: Quality Development; 3: Sustainable Institutionalization; Furco, 2002; Seifer and Connors, 2007). The next steps are to enhance comparative research in the Third Sector and provide funding mechanisms on a national level for this purpose. Policy makers are asked to set incentives for teachers' engagement (Abes et al., 2002).

\section{Leaving Scattered Institutional Practice Behind-Coordinated Action}

The future must be shaped by coordinated action on a national and institutional level. First, the emerging network initiated by the authors in 2019 must continue. Second, locating Third Sector activities in university's transfer offices is useful for coordinated action, reporting and monitoring. However, concepts need to be adapted to the respective circumstances such as students' profiles, and urban or rural structures of the HEI.

Networking should not only continue on national level, social innovation and service learning courses should not be considered as stand-alone initiatives, but become increasingly interconnected instead. Central coordinators on faculty level can enable and facilitate cooperation between teachers and provide possibilities to exchange expertise (Pigza and Troppe, 2003). 


\section{Modes of Recognition}

Eventually, service learning should be an indicator of teaching quality in the evaluation processes of academics. Analyzing the factors that motivate staff to implement service learning, the faculty reward structure plays a significant role, but is generally under-researched (Abes et al., 2002).

\section{DISCUSSION}

This policy brief is an attempt to summarize relevant national policy development and institutional practices to shed light on the Austrian developments.

We reviewed the available legally binding documents as key strategic policies for the Social Dimension in HE, which serve as a documentation of developments in Austria. The Third Mission activities of HEIs are still scattered, but ultimately with support from top management, are essential for uplifting this Sector to a strategic and more visible level.

In summary, many institutional practices shape the Third Sector in Austria. Yet, the authors are the first to initiate a common policy brief and to acknowledge cross-institutional

\section{REFERENCES}

Abes, E. S., Jackson, G., and Jones, S. R. (2002). Factors that motivate and deter faculty use of service-learning. Michigan. J. Comm. Serv. Learn. 9, 5-17. Available online at: http://hdl.handle.net/2027/spo.3239521.0009.101

Aramburuzabala, P., McIlrath, L., and Opazo, H. (2019). Embedding Service Learning in European Higher Education. Developing a Culture of Civic Engagement. London: Routledge.

BEPA (2010). Empowering People, Driving Change: Social Innovation in the European Union. Bureau of European Policy Advisors. (Luxembourg: Publications Office of the European Union). Available online at: https:// ec.europa.eu/migrant-integration/librarydoc/empowering-people-drivingchange-social-innovation-in-the-european-union

BMBWF (2017). National Strategy on the Social Dimension of Higher Education. Towards More Inclusive Access and Wider Participation. Brief Summary. Austria. Vienna: Federal Ministry of Science, Research and Economy (BMBWF).

Boyer, E. (1996). The scholarship of engagement. J. Public Serv. Outreach 1, 11-20. doi: $10.2307 / 3824459$

Bringle, R. G., and Hatcher, J. A. (1996). Implementing service-learning in higher education. J. Higher Educ. 67, 221-239. doi: 10.2307/2943981

Brower, H. H. (2011). Sustainable development through service learning: a pedagogical framework and case example in a third world context. Acad. Managem. Learn. Educ. 10, 58-76. doi: 10.5465/amle.10.1.zqr58

Buber, R., Ivanova, E., Mackerle-Bixa, S., Meyer, M., and Rameder, P. (2019). "Volunteering@wu: implementing community service learning in Austria," in University and Society: Inderdependencies and Exchange, eds Á. Kövér and G. Franger (Cheltenham: Edward Elgar Publishing), 180-198.

Butin, D. W. (2010). Service-Learning in Theory and Practice. The Future of Community Engagement in Higher Education. New York, NY: Palgrave Macmillan.

Cipolle, S. (2004). Service-learning as a counter-hegemonic practice: evidence pro and con. Multicul. Educ. 11,12-23.

Codispoti, F. (2004). "A justification of the communitarian model", in ServiceLearning: History, Theory, and Issues, eds B. W. Speck and S. L. Hoppe (Westport: Praeger), 99-118.

Dewey, J. (1966). Democracy and Education. New York, NY: Free Press (Original published 1916) learning in this field. Still, there is a lack of empirical research about the effects of policies on a societal, institutional and individual level (Fernandez and Slepcevic-Zach, 2018). We would appreciate a stronger strategic European movement in the Third Sector, however, mainstreaming of service learning can be viewed optimistically if the policy conditions in the Third Sector remain stable. More future research is needed about the Third Sector learning processes of HEIs as organizations. Building a strong Austrian research and practice network across and within disciplines has become an important work for our future.

\section{AUTHOR CONTRIBUTIONS}

KR substantial contribution to the policy brief, drafting the work, and critical revising for important intellectual content. MF substantial contribution to the policy brief and drafting the work. CF major contribution to the policy brief and critical revising for important intellectual content. PS-Z, MK, and PR minor contribution to the policy brief. All authors contributed to the article and approved the submitted version.

Dukhan, N., Schumack, M. R., and Daniels, J. J. (2009). Service learning as pedagogy for promoting social awareness of mechanical engineering students. Int. J. Mech. Eng. Edu. 37, 78-86. doi: 10.7227/IJMEE.37.1.7

Ehrlich, T. (1996). "Foreword," in Service-Learning in Higher Education: Concepts and Practices, eds B. Jacoby and Associates (San Francisco: Jossey-Bass), xi-xvi.

Evers, A., and Laville, J. L. (2004). The Third Sector in Europe. Northhampton: Edward Elgar Publishing.

Felten, P., and Clayton, P. H. (2011). Service-learning. New Direct. Teach. Learn. 2011, 75-84. doi: 10.1002/tl.470

Fernandez, K., and Slepcevic-Zach, P. (2018). Didaktische Modellierung einer Service-learning-Lehrveranstaltung - Ergebnisse eines designbased-Researchansatzes. Unterrichtswissenschaft. 46, 165-184. doi: 10.1007/s42010-017-0002-8

Furco, A. (2002). Self-Assessment Rubric for the Institutionalization of ServiceLearning in Higher Education. Berkeley: University of California.

Gerholz, K. H., and Losch, S. (2015). "Can service learning foster a social responsibility among students? - A didactical analysis and empirical casestudy in business education at a German university," in Corporate Social Responsibility: Locating the Missing Link, eds L. O'Riordan, S. Heinemann, and P. Zmuda (Wiesbaden: Springer Gabler), 599-622.

Grogan, M., and Fahrenwald, C. (2018). "Networks between universities and community organizations in teacher education," in Organisation und Netzwerke. Beiträge der Kommission Organisationspädagogik, eds S. M. Weber, C. Schröder, I. Truschkat, L. Peters, and A. Herz (Wiesbaden: VS Verlag), 241-250.

GUNI (2009). Higher Education at a Time of Transformation. New Dynamics for Social Responsibility. Available online at: http://www.guninetwork.org/report/ synthesis-guni-higher-education-world-reports-1-3

Harkavy, I., and Benson, L. (1998). De-platonizing and democratizing education as the bases of service learning. New Direct. Teach. Learn. 73, 11-20. doi: $10.1002 / \mathrm{tl} .7302$

Holland, B. (2005). "Reflections on Community-Campus Partnerships: What has been learned? What are the next challenges?" in Higher Education Collaboratives for Community Engagement and Improvement, eds P. Pasque, B. Mallory, R. Smerek, B. Dwyer, and N. Bowman (Ann Arbor: National Forum on Higher Education for the Public Good), 10-17.

Maassen, P., Andreadakis, Z., Gulbrandsen, M., and Stensaker, B. (2019). The Place of Universities in Society. Hamburg: Körber-Stiftung. 
McNall, M., Barnes-Najor, J. V., Brown, R., Doberneck, D., and Fitzgerald, H. (2015). Systemic engagement: universities as partners in systemic approaches to community change, J. Higher Educ. Out. Engagem. 19, 7-32.

Meijs, L., Maas, S. A., and Aramburuzabala, P. (2019). "Institutionalisation of service learning in European higher education," in Embedding Service Learning in European Higher Education. Developing a Culture of Civic Engagement, eds P. Aramburuzabala, L. McIlrath, and H. Opazo (London: Routledge), 214-229.

Meyer, M., Moder, C. M., Neumayr, M., and Vandor, P. (2019). Civil society and its institutional context in CEE. Voluntas. 1-17. doi: 10.1007/s11266-019-00106-7

Meyer, M., and Schachermayer-Sporn, B. (2018). Leaving the ivory tower: universities' third mission and the search for legitimacy. Zeitschr. Hochschulentwickl. 13, 41-60. doi: 10.3217/zfhe-13-02/03

Nigro, G. (2017). "Community-based research," in The Cambridge Handbook of Service Learning and Community Engagement, eds C. Dolgon, T. D. Mitchell, and T. K. Eatman (Cambridge: Handbooks in Psychology, Cambridge University Press), 158-167.

Nowotny, H., Scott, P., and Gibbons, M. (2003). Introduction: 'Mode 2' revisited: the new production of knowledge. Minerva Special Issue 41, 179-194. doi: 10.1023/A:1025505528250

Pigza, J., and Troppe, M. (2003). "Developing an infrastructure for service-learning \& community engagement," in Building Partnerships for Service-Learning, ed B. Jacoby (San Francisco: Jossey-Bass), 106-130.

Raddon, M. B., and Harrison, B. (2015). Is service-learning the kind face of the neo-liberal University? Can. J. Higher Educ. 45, 134-153.

Regierungsprogramm (2020). Aus Verantwortung für Österreich. Regierungsprogramm 2020 - 2024. Available online at: https://www. dieneuevolkspartei.at/Download/Regierungsprogramm_2020.pdf

Reinders, H. (2016). Service Learning - Theoretische Überlegungen und empirische Studien zu Lernen durch Engagement. Weinheim: Beltz.
Republic of Austria (2011). Strategie zum Lebensbegleitenden Lernen in Österreich. LLL 2020. Wien.

Resch, K. (2018). Third Mission and service learning. A narrative evaluation of the relevance of students' experiences. Zeitschrift Hochschulentwicklung 13, 127-139. doi: 10.3217/zfhe-13-02/08

Seider, S., Huguley, J. P., and Novick, S. (2013). College students, diversity, and community service learning. Teachers College Record. 115, 1-44.

Seifer, S. D., and Connors, K. (2007). Community Campus Partnerships for Health. Faculty Toolkit for Service-Learning in Higher Education. Scotts Valley: National ServiceLearning Clearinghouse.

Slaugther, S., and Rhoades, G. (2000). The neo-liberal university. New Labor Forum. 6, 73-79.

Slepcevic-Zach, P. (2017). Service-learning in der wissenschaftlichen Berufsvorbildung von Wirtschaftspädagog/inn/en - Ergebnisse einer mixed-methode-Studie. Zeitschrift Berufs Wirtschaftspädagogik, 113, 303-324.

Wohnig, A. (2016). Political learning by social engagement? Chances and risks for citizenship education. Citizenship Soc. Econ. Educ. 15, 244-261. doi: $10.1177 / 2047173416676493$

Conflict of Interest: The authors declare that the research was conducted in the absence of any commercial or financial relationships that could be construed as a potential conflict of interest.

Copyright (C) 2020 Resch, Fellner, Fahrenwald, Slepcevic-Zach, Knapp and Rameder. This is an open-access article distributed under the terms of the Creative Commons Attribution License (CC BY). The use, distribution or reproduction in other forums is permitted, provided the original author(s) and the copyright owner(s) are credited and that the original publication in this journal is cited, in accordance with accepted academic practice. No use, distribution or reproduction is permitted which does not comply with these terms. 